\title{
STRUT AND TIE MODEL STRUKTUR BALOK TINGGI BERLUBANG
}

\author{
Kamila Shaomi Nazila ${ }^{1)}$, YulitaArni Priastiwi ${ }^{2)}$, Sukamta $^{3)}$ \\ Departemen Teknik Sipil, Universitas Diponegoro, Semarang \\ Kamila.nazila@yahoo.co.id ${ }^{1)}$, yulitaarnipriastiwi@lecturer.undip.ac.id ${ }^{2)}$, \\ sukamta@lecturer.undip.ac.id ${ }^{3)}$
}

DOI: http://dx.doi.org/10.29103/tj.v11i1.362

(Received: August 2020 / Revised: December 2020 / Accepted: January 2021)

\begin{abstract}
Abstrak
Mendesain suatu bangunan tingkat tinggi dengan tidak menggunakan plafon dibutuhkan perencanaan yang ekonomis tanpa mengurangi kekuatan dan keindahan dari bangunan tersebut. Balok tinggi berlubang dengan material struktur beton digunakan untuk menghindari terjadinya sistem utilitas pada suatu bangunan tingkat tinggi dengan tidak menggunakan plafon. Balok tinggi berlubang ini ditinjau menggunakan metode Strut and Tie Model (STM). Untuk mengatasi permasalahan yang ada biasanya para perencana merancang daerah D (Disturbed Region) dengan menggunakan konsep pendetailan berdasarkan aliran gaya, sehingga metode strut and tie merupakan pendekatan yang sesuai untuk menganalisis struktur beton di daerah D. Program analisa struktur digunakan untuk melakukan analisis gaya dalam berupa momen dan geser pada struktur beton balok tinggi berlubang. Hasil analisis yang diperoleh pada struktur beton balok tinggi berlubang yaitu bahwa semakin dekat lubang balok dengan tumpuan maka nilai tulangan lentur akan lebih tinggi dan semakin bertambah pula tulangan gesernya.
\end{abstract}

Kata kunci: Balok Tinggi Berlubang, Daerah D, Metode Strut and Tie

\begin{abstract}
Designing a high rise building without using a ceilings requires an economical plan without reducing the strength and the art of the building. The deep beam with holes, which have the structure of concrete materials is need to be used to avoid the utility system in a high rise building without ceilings. This deep beam with holes is reviewed by the Strut and Tie Model (STM) method. To solve the existing problems, planners usually design the D region (Disturbed Region) use the concept of detail based on the flow of force. So the strut and tie method is an appropriate method to analyze the structure of concrete at D region (Disturbed Region). The program of analysis structure is used to analyze the internal forces, which are Moment and Shear, in the deep beams with holes' structure. The result of the analysis in the deep beam concrete with holes is the more position of the hole is close to its pedestal, the value of the Flexural reinforcement will be more increase, and teh Shear reinforcement will be higher too.
\end{abstract}

Keywords: Deep Beam Hollow, D Region, Strut and Tie Model

Strut And Tie Model Struktur Balok Tinggi Berlubang - Kamila Shaomi Nazila, YulitaArni Priastiwi, Sukamta 


\section{Latar Belakang}

Mendesain suatu bangunan dibutuhkan perencanaan yang ekonomis tanpa mengurangi kekuatan maupun keindahan bangunan tersebut. Pada bangunanbangunan tinggi saat ini umumnya menggunakan material beton bertulang. Untuk menambah ruang pada suatu bangunan para perencana menambah ruang pada bangunan tanpa merusak dari segi estetika bangunan tersebut. Salah satu cara yang dibutuhkan ialah dengan tidak menggunakan plafon di bangunan sehingga tinggi bangunan akan lebih tinggi dari bangunan biasanya. Namun hal ini akan berdampak pada utilitas bangunan yaitu suatu kelengkapan fasilitas yang digunakan untuk menunjang tercapainya unsur-unsur kenyamanan, kesehatan, keselamatan, kemudahan komunikasi dan mobilitas dalam pembangunan. Dampak utilitas ini banyak dijumpai pada bangunan tingkat tinggi yang dapat dilihat dari system supply air bersih, system pembuangan dan pengelolaan limbah cair dan limbah padat, system pencahayaan, elektrikal dan mekanikal, system pengudaraan, dan sebagainya.

Agar bangunan yang didesain tidak terdampak terhadap system ulititas tersebut, maka dilakukan penelitian dengan menggunakan balok tinggi berlubang dengan material beton bertulang. Diharapkan dengan menggunakan beton berlubang ini, system utilitas pada bangunan gedung dapat berfungsi sebagai mana mestinya.

Menurut (SNI 2847, 2019) mengenai persyaratan beton structural untuk bangunan gedung dan penjelasannya, balok tinggi merupakan komponen struktur yang dibebani satu sisi dan ditopang pada muka yang berlawanan sedemikian sehingga komponen tekan seperti strat dapat terbentuk diantara beban dan tumpuan yang memenuhi bentang bersih tidak melebihi empat kali tinggi keseluruhan komponen $\mathrm{h}$ (tinggi) dan beban terpusat berada dalam jarak $2 \mathrm{~h}$ dari muka tumpuan.

Perilaku balok tinggi didiskusikan dalam (Schlaich et al., 1987), (Rogowsky \& MacGregor, 1986) dan (Marti, 1985), untuk balok tinggi memikul beban gravitasi, ketentuan ini berlaku jika beban dikerjakan pada bagian atas balok dan balok ditumpu pada sisi bawahnya. Jika beban dikerjakan hingga ketepi atau bagian bawah komponen tersebut, model strut and tie (STM), harus digunakan untuk mendesain tulangan yang mentransfer secara internal beban ke sisi atas balok dan mendistribusikannya ketumpuan terdekat. Beberapa jurnal mengenai balok tinggi ini juga telah dikaji oleh (Pranata \& Suryoatmono, 2019) mengenai perilaku keruntuhan balok tinggi dengan pemodelan numerik, (Misbakhul Munir, Zulfikar Djauhari, 2014) mengenai analisis balok tinggi dengan beban merata dan menggunakan metode stut and tie, (Fitrianti et al., 2013) mengenai perencanaan ulang balok tinggi pada gedung rusunawa UMM, (Anggarini et al., 2018) mengenai pemodelan balok tinggi pada beton mutu tinggi dengan pengekangan dan menggunakan metode elemen hingga dan (Zaborac et al., 2020) mengenai perilaku balok dengan perkuatan di web, masing-masing menggunakan program analisa struktur yang berbeda untuk menganalisis numerik pada balok tinggi ini.

Komponen utama metode strut and tie terdiri atas elemen tekan (compressive struts), elemen tarik (tension ties) dan elemen nodal (nodal zone) sebagai zona pertemuan antar aelemen-elemen tekan dan elemen-elemen tarik. Berdasarkan distribusi tegangan dan regangannya, komponen struktur beton

Strut And Tie Model Struktur Balok Tinggi Berlubang - Kamila Shaomi Nazila, YulitaArni Priastiwi, Sukamta 
dikelompokkan dalam dua bagian struktur yaitu, bagian struktur di mana trajektori tegangannya mempunyai pola aliran yang relative seragam atau teratur (Daerah B/Bernoulli Region) dan bagian struktur yang trajektori tegangannya tidak teratur atau berpola turbulen (Daerah D/Disturbed Region).

Berdasarkan hasil penelitian (Patil et al., 2013) dapat diketahui bahwa keruntuhan utama balok tinggi adalah disebabkan oleh retak geser diagonal yang terjadi pada badan balok dan semakin tinggi balok maka kekuatan lentur balok juga akan meningkat.

Dalam penulisan ini akan dibahas mengenai penggunaan balok tinggi berlubang pada bangunan gedung tingkat tinggi dengan menggunakan metode strut and tie model (STM) untuk melihat gaya-gaya yang terjadi dan jumlah tulangan tarik dan tekan pada balok tinggi berlubang tersebut. Penulisan ini bertujuan melihat pengaruh lubang pada balok tinggi terhadap tulangan geser dan tulangan lentur bangunan gedung tingkat tinggi yang tidakmenggunakan plafon.

\section{Metode Penelitian}

\subsection{Strut and Tie Model (STM)}

Menurut (Schlaich et al., 1987) secara sistematik mengembangkan langkah perencanaan struktur beton bertulang dengan Strut and Tie Model, yaitu dengan membagi struktur dalam dua daerah yakni daerah D dan B. Daerah yang tidak lagi datar dan tegak lurus garis netral sebelum dan sesudah ada tambahan lentur yang dirincikan oleh regangan non linier, disebut daerah D (DistributedatauDiscontinuity) dan daerah di mana berlaku hukum Bernoulli disebut daerah B (BendingatauBernoulli). Kedua daerah tersebut menggambarkan alur gaya (Load Path) sebagai transfer gaya yang terjadi pada struktur beton bertulang pada struktur beton bertulang pada kondisi retak dari sumber pembebannya sampai tumpuan (Hardjasaputra, H dan Tumilar S, 2002).

Metode strut and tie adalah sebuah metode yang didasarkan pada system keseimbangan gaya-gaya yang bekerja pada sebuah struktur ketika dibebani. Pada dasarnya metode ini digunakan untuk menganalisis dan memodelkan suatu struktur beton bertulang yang dapat memikul gaya-gaya di dalamnya seperti, gaya lentur, gaya geser dan gaya torsi yang mengacu kepada teori keseimbangan desain plastis. Metodestrut and tie dapat digunakan pada daerah-daerah di mana teori balok tidak dapat diterapkan. Dengan metode strut and tie model, analisa daerah D pada elemen struktur dapat lebih mudah dilakukan di mana keadaan tegangan yang terjadi diidealisasikan sebagai strut dari beton dan tie dari baja dan daerah nodal (Lumantarna, 2002).

Metode strut and tie ini digunakan dalam beberapa penelitian diantaranya; (Afrizal, 2011) digunakan sebagai alternative perancangan struktur beton bertulang, (Dhahir, 2018) digunakan pada geser balok tinggi yang diperkuat dengan laminasi FRP, (Deng et al., 2018) digunakan melihat kekuatan geser balok tinggi HDC, (Chen et al., 2018) digunakan untuk mengevaluasi kekuatan geser yang diperkuat balok tinggi dan (Hanoon et al., 2017) digunakan sebagai factor efektivitas untuk kedalaman beton yang diperkuat menggunakan lembaran CFRP, metode ini didasarkan pada pemahamanan yang dibagi menjadi 2 bagian yaitu, daerah D dan daerah B pada struktur beton bertulang.

Strut And Tie Model Struktur Balok Tinggi Berlubang - Kamila Shaomi Nazila, YulitaArni Priastiwi, Sukamta 
Struktur seperti balok tinggi (deep beam) mengandung daerah D. ACI 31814 menjelaskan bahwa suatu balok dinyatakan sebagai balok tinggi dalam perencanaan lentur bila rasio bentang bersih balok dibandingkan tinggi balok $L n / d \leq 1,25$ untuk di atas dua tumpuan dan $L n / d \leq 2,5$ untuk balok di atas beberapa tumpuan. Selanjutnya balok dinyatakan sebagai balok tinggi dalam perencanaan geser bila $h / d \leq 5,0$ dan balok tersebut dibebani dari permukaan atas serta ditumpu pada sisi bawah balok.

Komponen-komponen dari model strut and tie dari balok bentang tunggal yang memuat beban dapat dilihat pada Gambar 1, yang menjelaskan dimensi cross-sectional dari penyangga atau tie merupakan ketebalan dan lebar dari kedua arah tegak lurus terhadap sumbu penyangga atau tie. Ketebalan tegak lurus terhadap bidang, dan lebar pada bidang model strut and tie. Ikatan terdiri dari tulangan non pratekan atau pratekan ditambah sebagian beton di sekitar pusat yang sama dengan sumbu ikatannya. Beton yang mengelilinginya dimasukkan untuk menentukan zona di mana gaya dalam ikatan harus sesuai. Beton pada tie tidak digunakan untuk menahan gaya aksial pada tie/penyangga. Meskipun tidak secara langsung dipertimbangkan dalam desain, beton disekitarnya akan mengurangi perpanjangan ikatan, terutama pada beban layan (ACI 318-14).

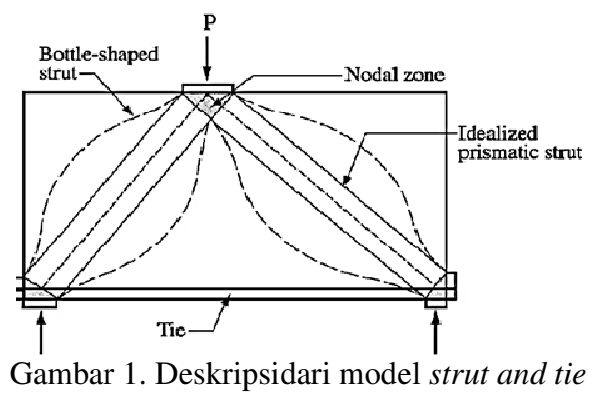

(ACI 318-14)

Pada ACI 318-14 mengenai perencanaan untuk struktur beton, dalam mendesain strut, tie dan nodal menggunakan persamaan (1).

$$
\phi F_{n} \geq F_{u}
$$

di mana:

$F_{n}$ = gaya dalam strut and tie ataugaya yang berada pada zona nodal yang merupakanfaktorbeban,

$F_{u}=$ kekuatan nominal daristrut, tie atau zona nodal,

$\emptyset=$ faktor reduksi.

Menurut ACI 318-14 untuk menghitung kekuatan normal tekan strut tanpa tulangan longitudinal menggunakan persamaan (2).

$$
F_{n s}=f_{c e} A_{c s}
$$

di mana:

$F_{Y g}=$ kekuatan nominal dari strut ,

$f_{g z}=$ kuat tekan efektif beton dari strutatau zona nodal,

$A_{c s}=$ luas penampang disalah satu ujung strutdalam STM, diambil tegak lurus terhadap sumbu strut. 
Kuat tekan efektif beton dari strut atau zona nodal dihitung menggunakan persamaan (3).

$$
f_{c e}=0,85 \beta_{s} f_{c}^{\prime}
$$

di mana:

$$
\begin{aligned}
& f_{c e}=\text { kuat tekan efektif beton dari strutatau zona nodal, } \\
& \hat{\beta}_{o}=\text { koefisien strut } \\
& f_{c}{ }^{\prime}=\text { kuat tekan beton. }
\end{aligned}
$$

Menurut ACI 318-14, kekuatan tie harus memenuhi $\phi S_{n} \geq U$ untuk setiap kombinasi beban terfaktor yang berlaku. Kekuatan tie pada batang tarik tie dalam kondisi layan (serviceability state) perlu diperiksa lebar retaknya dengan melalui pembatasan lebar retak atau dengan melalui pembuatan tegangan baja yang lebih rendah. Gaya tarik ini dapat dihitung dengan persamaan (4).

$$
\phi F_{n t} \geq F_{u t}
$$

di mana,

$F_{u t}=$ faktor kekuatan tarik dari tie,

$F_{m t}=$ kekuatan nominal dari tie yang dicari menggunakan persamaan (5).

$$
F_{n t}=A_{t s} f_{y}+A_{t p}\left(f_{s e}+\Delta f_{p}\right)
$$

di mana,

$$
\begin{aligned}
& A_{v z}=\text { luasan tulangan }\left[\mathrm{mm}^{2}\right], \\
& A_{t p}=\text { luasan baja tendon prategang }\left[\mathrm{mm}^{2}\right], \\
& f_{y}=\text { mutu baja [MPa] } \\
& f_{z z}=\text { tegangan efektif yang hilang didalam baja tendon prategang [MPa], } \\
& \Delta f_{p}=\text { penambahan gaya prategang disamping level load. }
\end{aligned}
$$

Dengannilai $f_{g \theta}+\Delta f_{p}$ tidak melebihi $f_{p y}$ dan $A_{t p p}$ sama dengan nol untuk elemen non prategang.

\subsection{B-Region dan D-Region}

Pada komponen struktur beton distribusi tegangan dan regangan dikelompokkan menjadi dua bagian yaitu, daerah B (Bernoulli Region) dan daerah D (Disturbed Region). Pada daerah B (Bernoulli Region), berlaku asas Bernoulli di mana bidang datar penampang akan tetap merupakan bidang datar setelah pembebanan dan distribusi regangan pada penampang bersifat linear dan proporsional terhadap jarak dari sumbu netral penampang, sedangkan pada daerah D (Disturbed Regional) yang biasanya terjadi di daerah dekat perletakkan, daerah dekat beban terpusat, daerah dekat bukaan dan pada daerah di mana terjadi perubahan ukuran dan bentuk penampang yang ekstrim. Asas Bernoulli tidak dapat diterapkan karena tegangan bersifat tidak teratur dan distribusi regangan pada penampang menjadi tidak linear.

Daerah D (disturbed Region) atau daerah yang tidak datar lagi dapat ditentukan dengan menggunakan prinsip St Venant's dengan perencanaanya menggunakan metode strut and tie (STM) sedangkan pada daerah B (Bernoulli Region) tegangan dapat dicari menggunakan momen lentur dengan 
perencanaannya dapat menggunakan model rangka batang (Modified Compression Field $\mathrm{MCF}$ ).

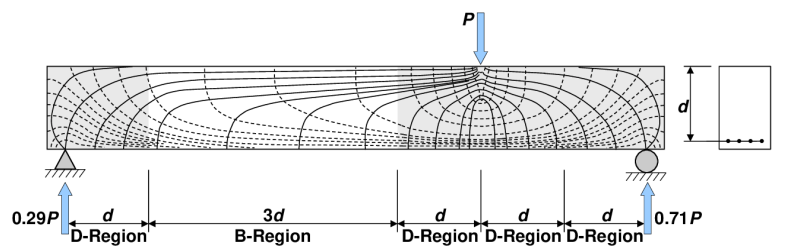

Gambar 2 B-region dan D-region
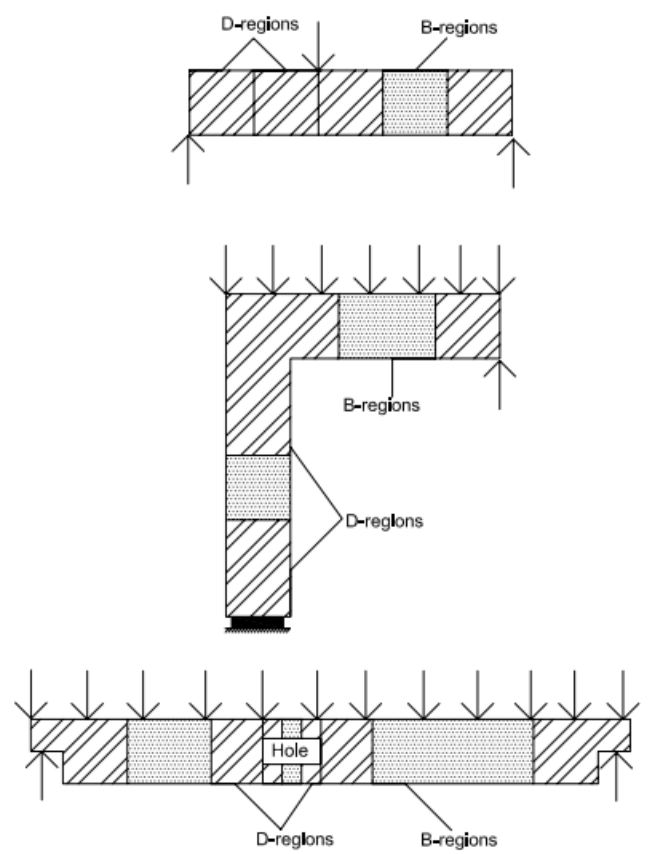

Gambar 3 B-region dan D-region

Peraturan ACI 318-14 menyebutkan bahwa diskontinuitas dalam distribusi tegangan tejadi pada perubahan geometri elemen struktural atau pada beban atau reaksi yang terkonsentrasi. Prinsip St Venant's menunjukkan bahwa tekanan akibat gaya aksial dan tekuk mendekati distrbusi linear pada jarak yang sama dengan kedalaman keseluruhan h, jauh dari diskontinuitas. Dengan melihat ini maka daerah diskontiuitas diasumsikan untuk memperpanjang jarak $\mathrm{h}$ dari bagian di mana beban atau perubahan geometri terjadi.

Daerah yang diarsir pada Gambar 3 dan Gambar 4 menunjukkan daerah D (Disturbed Region) yang khas (Schlaich et al. 1987). Secara umum, setiap bagian dari anggota di luar daerah D (Disturbed Region) adalah daerah B (Bernoulli Region) di mana asumsi bagian bidang teori lentur dapat diterapkan. Metode desain strut and tie model (STM) didasarkan pada asumsi bahwa daerah D (Disturbed Region) dapat dianalisis dan dirancang menggunakan hipotesis pinjointed trusses yang terdiri dari struts dan ikatan yang terhubung pada node. 


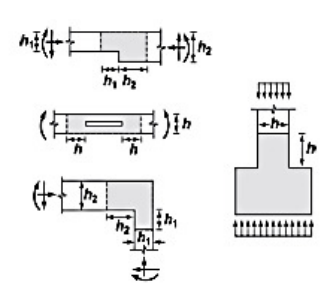

(a)

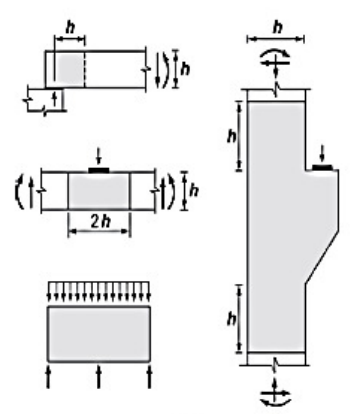

(b)

Gambar 4 (a) GeometriDiskontinu; (b) Beban dan Geometri Diskontinu

Sesuai dengan peraturan di dalam ACI 318-14, langkah-langkah prosedur dalam mendesain struktur dengan menggunakan model strut and tie:

1. Mengecek kapasitas daya pikul pada daerah tumpuan dan pembebanan pada balok.

2. Menentukan model strut and tie pada balok

3. Menghitung gaya dalam yang terjadi pada rangka batang

4. Mendesain pada zona nodal

5. Mengecek kekuatan strut dan lebar tie yang diperlukan

6. Menentukan penulangan pada tie

7. Mengecek pengangkurannya

8. Menghitung kebutuhan tulangan yang dibutuhkan untuk mengontrol retak pada balok

9. Menggambarkanlayout penulangan pada balok yang ditinjau.

\subsection{Metode}

Penulisan ini merujuk pada model penulisan sebelumnya yaitu, analisa balok tinggi berlubang dengan metoda strut and tie model (Marpaung, et al. 2012). Pada penulisan ini dibahas mengenai analisa balok tinggi berlubang dengan kedua ujung balok ditumpu sederhana menggunakan sendi dan rol, dengan berat sendiri pada balok diabaikan dan beban yang bekerja pada balok yaitu beban terfaktor (dua beban terpusat). Variasi dari balok tinggi berlubang ini terletak pada letak lubangnya yaitu, lubang yang terletak di tengah bentang, di bawah kedua beban terpusat juga diantara beban dan tumpuan. Penulisan ini mengacu pada peraturan ACI 318-14 untuk ketentuan mengenai STM (Strut and Tie Model) mengenai pembatasan tulangan dan pengangkuran. Bila penulis sebelumnya menggunakan program SAP2000 dalam analisisnya, perhitungan gaya dalam pada analisis balok tinggi berlubang ini digunakan program analisa struktur lainnya.

\subsection{PemodelandenganMetode STM}

Pemodelan balok tinggi berlubang ini menggunakan metode strut and tie dengan 4 (empat) variasi balok yaitu; balok variasi 1 (balok dengan sepanjang bentang tanpa adanya lubang atau balok utuh), balok variasi 2 (balok dengan adanya 1 lubang pada bagian tengah bentangnya, 1/2 L), balok variasi 3 (balok dengan adanya 2 lubang tengah kedua beban terpusat yang ada, 1/3 L) dan balok variasi 4 (balok dengan adanya 2 lubang diantara tumpuan dan beban yang ada,

Strut And Tie Model Struktur Balok Tinggi Berlubang - Kamila Shaomi Nazila, YulitaArni Priastiwi, Sukamta 
1/6 L). Dua beban yang digunakan pada baloktinggi ialah beban terpusat $(\mathrm{P})$ sebesar $100 \mathrm{kN}$. Gambar untuk keempat variasi balok seperti diperlihatkan pada Gambar $5 \mathrm{~s} / \mathrm{d} 8$. Data lain yang digunakan pada penulisanini ialah:

1. Dimensi Balok $B=300 \mathrm{~mm} ; H=600 \mathrm{~mm}$

2. Dimensi Lubang $L=800 \mathrm{~mm} ; B=300 \mathrm{~mm} ; H=600 \mathrm{~mm}$

3. $f c^{\prime}=30 \mathrm{MPa}$

4. $f_{y}=400 \mathrm{MPa}$

5. $s=40 \mathrm{~mm}$

6. Faktor reduksi kekuatan untuk strut, tie and nodal zone $(D)=0,75$.

Variasi model yang digunakan terdiri dari 4 variasi yang ditunjukkan pada Gambar 5 s/d Gambar 8

a. Balok variasi 1 (balok utuh atau balok tanpa lubang)

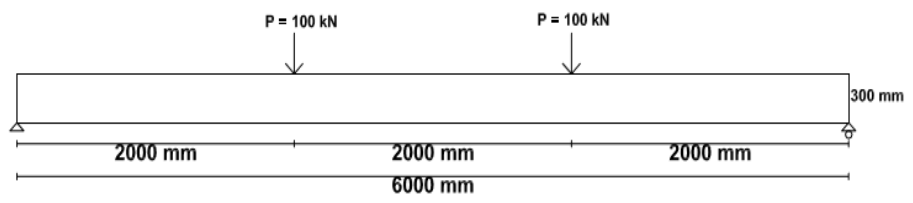

Gambar 5 Balok variasi 1

b. Balok variasi 2 (balok dengan adanya 1 lubang pada bagian tengah bentangnya, $1 / 2 \mathrm{~L}$ )

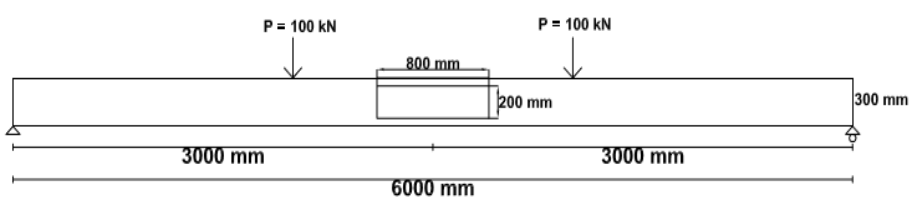

Gambar 6 Balok variasi 2

c. Balok variasi 3 (balok dengan adanya 2 lubang tengah kedua beban terpusat yang ada, $1 / 3 \mathrm{~L}$ )

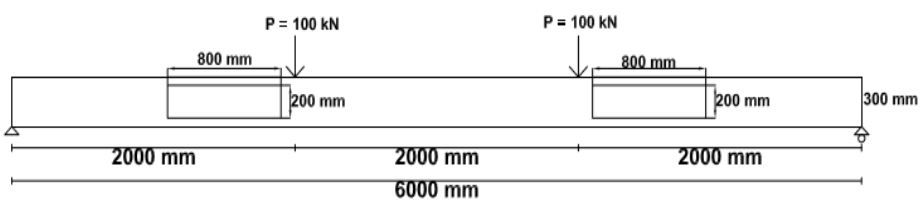

Gambar 7 Balok variasi 3

d. Balok variasi 4 (balok dengan adanya 2 lubang diantara tumpuan dan beban yang ada, 1/6 L)

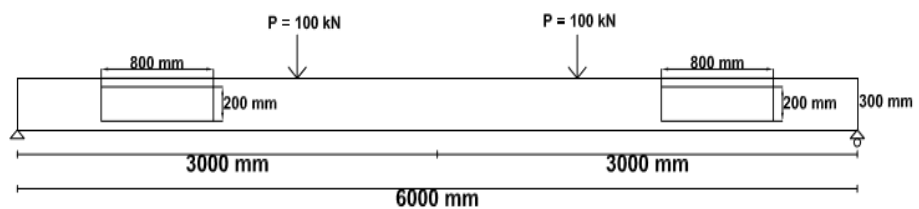

Gambar 8 Balok variasi 4

Strut And Tie Model Struktur Balok Tinggi Berlubang - Kamila Shaomi Nazila, YulitaArni Priastiwi, Sukamta 
Pembahasan hanya mencakup penyelesaian perhitungan gaya dalam rangka batang, perencanaan tulangan pada balok tinggi dan perbandingan hasil dengan menggunakan program yang berbeda dari penulisan sebelumnya, di mana gaya dalam pada balok didapatkan dari hasil output program ETABS 2015 dari hasil output yang didapat, dihitung tulangan yang dibutuhkan untuk balok tinggi yang ditinjau.

\section{Hasil dan Pembahasan}

Analisis gaya dalam yang digunakan untuk mencari tulangan lentur dan geser pada balok berlubang ini menggunakan program analisa struktur dan berikut hasil output yang didapatkan dari program analisa struktur.

Tabel 1 Output Gaya Dalam (Momen dan Geser) yang dihasilkandari Program

\begin{tabular}{ccc}
\multicolumn{3}{c}{ Analisa Struktur } \\
\hline Tipe balok & $\begin{array}{c}\mathrm{Mu} \\
(\mathrm{kN} . \mathrm{m})\end{array}$ & $\begin{array}{c}\mathrm{Vu} \\
(\mathrm{kN})\end{array}$ \\
\hline Balok Variasi 1 & 219.440 & 112.960 \\
\hline Balok Variasi 2 & 204.523 & 119.915 \\
\hline Balok Variasi 3 & 220.246 & 113.536 \\
\hline Balok Variasi 4 & 219.958 & 113.536 \\
\hline
\end{tabular}

Hasil gaya dalam yang diperoleh dalam Tabel 1 kemudian dipergunakan untuk memperhitungkan penulangan lentur dan geser dari model balok yang dibuat sepertiditunjukkan dalam Tabel 3, sedangkan dalamTabel 2 ditunjukkan perhitungan sebelumnya(Marpaung \& Tarigan, 2012)

Analisis balok tinggi berlubang ini, dilakukan perhitungan dari hasil output gaya dalam rangka batang yang didapatkan dari program analisa struktur lalu, dihitung perencanaan tulangan pada masing-masing variasi pada balok tinggi berlubang ini. Berikut hasil perhitungan yang didapatkan pada Tabel 3 dan dibandingkan dengan hasil perhitungan pada penelitian sebelumnya pada Tabel 2 yang menggunakan program SAP 2000 untuk menghitung gaya dalam pada balok tinggi berlubang ini.

Tabel 2 Penulangan Balok dengan SAP2000

\begin{tabular}{|c|c|c|c|c|c|}
\hline No & Keterangan & BalokUtuh & Baloktipe 1 & Baloktipe 2 & Baloktipe 3 \\
\hline \multirow{5}{*}{1} & TulanganLentur & & & & \\
\hline & - Tulangantekan & & 4D13 & 4D19 & 3D16 \\
\hline & - Tulangantarik & & 6D19 & 6D19 & 4D16 \\
\hline & - Bagian ataslubang & 6D19 & & 4D16 & 4D19 \\
\hline & - Bagian bawahlubang & & 2D13 & 4D19 & 6D16 \\
\hline \multirow{6}{*}{2} & TulanganGeser & & & & \\
\hline & - Tulanganpokok & D8-200 & D8-200 & D8-200 & D8-200 \\
\hline & - Bagian ataslubang & & & D10-200 & D13-250 \\
\hline & - Bagian bawahlubang & & & D8-200 & D13-300 \\
\hline & - Sisi kirilubang & & D10 & 2D16 & 2D19 \\
\hline & - Sisi kananlubang & & D10 & D10 & 2D19 \\
\hline
\end{tabular}

Sumber: (Marpaung \& Tarigan, 2012)

Strut And Tie Model Struktur Balok Tinggi Berlubang - Kamila Shaomi Nazila, YulitaArni Priastiwi, Sukamta 
Tabel 3 Tulangan berdasarkan hasil nilai Output Gaya dalam analisa struktur

\begin{tabular}{|c|c|c|c|c|c|}
\hline No & Keterangan & $\begin{array}{l}\text { Balok } \\
\text { Utuh }\end{array}$ & Balok tipe 1 & Balok tipe 2 & Balok tipe 3 \\
\hline \multirow{5}{*}{1} & TulanganLentur & & & & \\
\hline & - Tulangantekan & & 3D16 & 3D19 & 3D16 \\
\hline & - Tulangantarik & & 6D19 & 6D19 & 4D16 \\
\hline & - Bagian ataslubang & 4D22 & & 3D16 & 4D19 \\
\hline & - Bagian bawahlubang & & 2D16 & 3D19 & $6 \mathrm{D} 16$ \\
\hline \multirow{6}{*}{2} & TulanganGeser & & & & \\
\hline & - Tulanganpokok & D13-200 & D13-200 & D8-200 & D8-200 \\
\hline & - Bagian ataslubang & & & D10-200 & D16-250 \\
\hline & - Bagian bawahlubang & & & D10-200 & D13-300 \\
\hline & - Sisi kirilubang & & D13 & 3D16 & 2D19 \\
\hline & - Sisi kananlubang & & D13 & D13 & $2 \mathrm{D} 19$ \\
\hline
\end{tabular}

Hasil perencanaan tulangan seperti dalam Tabel 2 dan Tabel 3 menunjukkan perbedaan jumlah, jarak dan diameter tulangan yang digunakan karena penggunaan software hitung yang berbeda.

Berdasarkan data tulangan lentur pada Tabel 3, dapat dilihat bahwa:

- Pada bagian balok variasi 1 atau balok utuh (balok tidak berlubang) tidak diperlukannya tulangan tekan.

- Pada bagian balok variasi 2 (balok dengan adanya 1 lubang pada bagian tengah bentangnya, $1 / 2$ L) jika beban berada pada bagian tengah atas lubang maka jumlah dan diameter tulangan tekan akan maksimum, untuk tulangan tarik jumlah dan diameter tulangan sama, bagian atas lubang pada variasi ini tidak dibutuhkan adanya tulangan dan pada bagian atas lubang diameter dan jumlah tulangan akan semakin bertambah dikarenakan posisi lubang yang mendekati tumpuan.

- Pada bagian balok variasi 3 (balok dengan adanya 2 lubang tengah kedua beban terpusat yang ada, 1/3 L) jika posisi lubang lebih dekat dengan tumpuannya maka jumlah dan diameter tulangan tekan akan minimum, untuk tulangan tarik jumlah dan diameter tulangan sama, diameter tulangan pada bagian atas lubang akan semakin bertambah dan jumlah tulangan akan semakin bertambah dikarenakan posisi lubang yang mendekati tumpuan

- Pada bagian balok variasi 4 (balok dengan adanya 2 lubang diantara tumpuan dan beban yang ada, 1/6 L) jumlah dan diameter tulangan tarik akan berkurang, diameter tulangan pada bagian atas lubang akan semakin bertambah dan jumlah tulangan akan semakin bertambah dikarenakan posisi lubang yang mendekati tumpuan.

Berdasarkan data tulangan geser pada Tabel 3, dapat dilihat bahwa:

- Pada bagian balok variasi 1 atau balok utuh (balok tidak berlubang) untuk tulangan pokok sama diameter dan jarak tulangan yang digunakan dengan variasi lainnya.

- Pada bagian balok variasi 2 (balok dengan adanya 1 lubang pada bagian tengah bentangnya, $1 / 2$ L) untuk tulangan pokok sama diameter dan tulangan yang digunakan dengan variasi lainnya, bagian atas lubang dan bagian bawah lubang pada variasi ini tidak diperlukan diameter dan jarak dari tulangannya, sisi kiri 
lubang memiliki diameter tulangan akan bertambah sama dengan balok variasi 3 hal ini dikarenakan posisi lubang yang semakin dekat dengan tumpuan dan sisi kanan lubang jumlah dan diameter tulangan yang digunakan sama dengan balok variasi 3 .

- Pada bagian balok variasi 3 (balok dengan adanya 2 lubang tengah kedua beban terpusat yang ada, 1/3 L) untuk tulangan pokok sama diameter dan tulangan yang digunakan dengan variasi lainnya, bagian bawah lubang diameter dan jarak tulangan akan bertambah sama dengan balok variasi 4 dan sisi kiri lubang jumlah dan diameter tulangan bertambah sama seperti balok variasi 2 hal ini dikarenakan posisi lubang semakin dekat dengan tumpuannya, dan pada sisi kanan lubang jumlah dan diameter tulangan yang digunakan sama dengan balok variasi 2 .

- Pada bagian balok variasi 4 (balok dengan adanya 2 lubang diantara tumpuan dan beban yang ada, 1/6 L) untuk tulangan pokok sama diameter dan tulangan yang digunakan denganvariasi lainnya, bagian atas lubang diameter dan jarak antar tulangan bertambah sama dengan balok variasi 3, bagian bawah lubang semakin bertambah diameter dan jarak tulangannya sama dengan balok variasi, bagian sisi kiri lubang diameter tulangan bertambah dan pada bagian sisi kanan lubang jumlah dan diameter tulangan semakin bertambah hal ini dikarenakan posisi lubang mendekati tumpuannya.

\section{$4 \quad$ Kesimpulan dan Saran}

Pada penulisan ini, dapat disimpulan bahwa; jarak sengkang makin kecil kapasitas gesernya menjadi lebih besar dan sebaliknya, semakin lubang pada balok tinggi ini mendekati tumpuan, maka semakin besar diameter tulangan yang digunakan, baik itu pada tulangan geser maupun tulangan lentur, nilai tulangan lentur dan tulangan geser akan maksimum jika lubang pada balok semakin mendekati tumpuannya dan metode yang digunakan pada tulisan ini, yaitu metode strut and tie sangat cocok digunakan untuk menganalisis balok tinggi berlubang dikarenakan konsep pendetailan berdasarkan aliran gaya untuk menganalisis struktur beton di daerah D.

\section{UcapanTerima Kasih}

Terimakasih kepada dosen magister teknik sipil, keluarga, teman-teman dan pihak-pihak yang telah membantu untuk menyelesaikan penulisan ini, tanpa adanya pihak-pihak yang terkait tulisan ini tidak akan terlaksana dengan baik

\section{Daftar Kepustakaan}

Afrizal, Y. (2011). Strut and Tie Model Sebagai Alternatif Perancangan Struktur Beton Bertulang. Inersia Jurnal Teknik Sipil, 3(1), 39-44. https://ejournal.unib.ac.id/index.php/inersiajurnal/article/view/6704

Anggarini, E., Hayati, F., \& Setiawan, I. (2018). Pemodelan Balok Tinggi pada

Beton Mutu Tinggi dengan Pengekangan Menggunakan Perangkat Lunak Berbasis Metode Elemen Hingga 3D. Konstruksia, 9(2), 31-40. 
Chen, H., Yi, W. J., \& Hwang, H. J. (2018). Cracking strut-and-tie model for shear strength evaluation of reinforced concrete deep beams. Engineering Structures, 163(February), 396-408. https://doi.org/10.1016/j.engstruct.2018.02.077

Deng, M., Ma, F., Ye, W., \& Liang, X. (2018). Investigation of the shear strength of HDC deep beams based on a modified direct strut-and-tie model. Construction and Building Materials, 172, 340-348. https://doi.org/10.1016/j.conbuildmat.2018.03.274

Dhahir, M. K. (2018). Strut and tie modeling of deep beams shear strengthened with FRP laminates. Composite Structures, 193(September 2017), 247-259. https://doi.org/10.1016/j.compstruct.2018.03.073

Fitrianti, D. D., Septiropa, Z., \& Rommel, E. (2013). Perencanaan Ulang Balok Beton Bertulang Pada Gedung Rusunawa Umm Dengan Metode Strut and Tie. Jurnal Media Teknik Sipil, 9(2). https://doi.org/10.22219/jmts.v9i2.1198

Hanoon, A. N., Jaafar, M. S., Al Zaidee, S. R., Hejazi, F., \& Aziz, F. N. A. A. (2017). Effectiveness factor of the strut-and-tie model for reinforced concrete deep beams strengthened with CFRP sheet. Journal of Building Engineering, 12(May), 8-16. https://doi.org/10.1016/j.jobe.2017.05.001

Hardjasaputra, H. dan Tumilar, S., "Model Penunjang dan Pengikat (Strut-and-Tie Model) Pada Perancangan Struktur Beton", Penerbit Universitas Pelita Harapan, Jakarta, Agustus 2002.

Marpaung, M., \& Tarigan, D. J. (2012). Analisa Balok Tinggi Berlubang Dengan Metode Strut and Tie Model. 2(1).

Marti, P. (1985). reference_11.50.pdf. ACI Journal Proceedings, 82(4), 46-56.

Misbakhul Munir, Zulfikar Djauhari, I. R. S. J. (2014). Analisa Balok Tinggi Beton Bertulang Dengan Menggunakan Metode. 1-15.

Patil, S. S., Shaikh, A. N., \& Niranjan, B. R. (2013). Experimental and Analytical Study on Reinforced Concrete Deep Beam. International Journal of Mordern Engineering Research, 3(1), 45-52.

Pranata, Y. A., \& Suryoatmono, B. (2019). Pemodelan Numerik Perilaku Keruntuhan Balok Tinggi Beton Bertulang. Jurnal Teknik Sipil, 6(1), 42-62. https://doi.org/10.28932/jts.v6i1.1326

Rogowsky, D. M., \& MacGregor, J. G. (1986). Design of Reinforced Concrete Deep Beams. In Concrete International (Vol. 8, Issue 8, pp. 49-58).

Schlaich, J., Schaefer, K., \& Jennewein, M. (1987). Toward a Consistent Design of Structural Concrete. PCI Journal, 32(3), 74-150. https://doi.org/10.15554/pcij.05011987.74.150

SNI 2847. (2019). SNI 03-2847:2019 Persyaratan Beton Struktural Untuk Bangunan Gedung Dan Penjelasan Sebagai Revisi Dari Standar Nasional Indonesia 2847 $\square$ : 2013. In Badan Standarisasi Nasional (Issue 8).

Zaborac, J., Choi, J., \& Bayrak, O. (2020). Assessment of deep beams with inadequate web reinforcement using strut-and-tie models. Engineering Structures, $\quad 218$ (March), 110832. https://doi.org/10.1016/j.engstruct.2020.110832

Copyright (c) Kamila Shaomi Nazila, Yulita Arni Priastiwi, Sukamta Sukamta

Strut And Tie Model Struktur Balok Tinggi Berlubang - Kamila Shaomi Nazila, 52

YulitaArni Priastiwi, Sukamta 